\title{
Whose creative economy? Inequality and the need for international approaches
}

\author{
Qui s'approprie l'économie créative ? L'accentuation des \\ inégalités et la nécessité d'une approche internationale
}

\section{Cuya economía creativa? La desigualdad y la necesidad de enfoques internacionales}

Article inédit, mis en ligne le 3 octobre 2016.

\section{Kate Oakley}

Kate Oakley is Professor of Cultural Policy at the University of Leeds. Her interests are in labour in the cultural industries, inequality and local economic development.k.oaklev@leeds.ca.uk

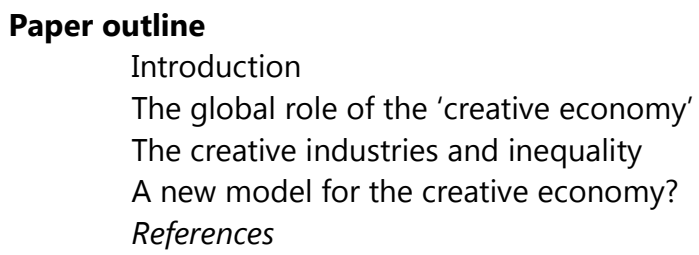

\begin{abstract}
This paper argues that the discourse of the creative economy as it has played out over the last fifteen years or so, is part of a model of 'globalisation' that is now exhausted. In particular, the absorption of previously progressive cultural policy aims such as increased cultural diversity, an ending of artificial barriers between 'high' and 'low' culture and a recognition of the importance of markets in cultural production, into a much narrower focus purely on 'jobs and growth' has meant that many culture-led developments, and the cultural sectors themselves, across the world simply reproduce social and economic inequality. A more pluralistic model of cultural development that pays attention to inequities in cultural work itself is desperately needed.
\end{abstract}

\section{Keywords}

Creative economy, inequality, international cultural policy.

\section{Résumé}

Cet article soutient que le discours de l'économie créative tel qu'il s'est déployé sur les quinze dernières années, s'inscrit dans un modèle de 'globalisation' désormais caduc. En particulier, l'absorption des objectifs passés des politiques culturelles progressistes - comme le renforcement de la diversité culturelle, la suppression de barrières entre culture élitiste et culture de masse, et la 
reconnaissance de l'importance du marché dans la production culturelle - dans un objectif plus étroit focalisé sur 'les emplois et la croissance', signifie que les développements de projets fondés sur la culture et les secteurs de la culture eux-mêmes, se bornent à reproduire à travers le monde l'inégalité sociale et économique. Un modèle de développement culturel plus pluraliste tenant mieux compte des iniquités dans l'action culturelle reste désespérément nécessaire.

\section{Mots clés}

Économie créative, inégalité, politique culturelle internationale.

\section{Resumen}

\section{Palabras clave}

Economía creativa, desigualdad, la política cultural internacional.

\section{Introduction}

It is with no small sense of irony that I am writing this paper in the immediate aftermath of the UK's vote to leave the $\mathbf{E U}$, with all its potentially seismic implications. Yet, crucial as this is for the UK and much as it is being represented as sui generis in some parts of the media, it is of course part of a wider shift across the Global North as the effects of the global financial crisis continue to play out and the Washington consensus model of economic globalisation comes undone. In its wake, increased social and economic inequality becomes the defining political issue of our times. Nationalistic parties are active and popular across much of the European Union, including countries such as Austria which could be seen to have survived the financial crisis, if not unscathed, then not exactly economically impoverished either. In other cases, the failure of both nation states and supra-national bodies such as the EU to protect their citizens from falling living standards, low pay and in some cases mass unemployment, particularly for the young, means that the immediate future is more like one of disintegration, rather than integration.

The almost thirty year period from the collapse of the Berlin wall until now has seen globalisation presented as if it were inevitable, almost 'natural', while protests from the Left in the form of the antiglobalisation movement from Seattle in 1999 onwards, and from the Right in the form of resurgent nationalistic parties, have been dismissed as utopian in the first instance and atavistic in the second. The European Union which had played a role both as a facilitator of globalisation and a protector of its citizens from the consequences, has begun to fail in this second role, as the social' European model has been eroded in favour of a more neoliberal one.

In a recent book (Bell \& Oakley, 2015:143), we argued that,

"While we seek to avoid some of the more excessive claims about globalisation, particularly the degree to which its represents a novel phenomenon, we do accept that there is increasing integration of the world economy, driven by deregulatory policy regimes, the emergence of global consumer 
markets and the growth of digital communications, among other factors. This is not a one-way process of 'Westernisation,' and there is no inevitability about its continuation."

That process of integration is clearly threatened with the possibility of trade wars and tariff barriers between states and undermined within states by unmanageable inequalities. But the growth in global consumer markets, the spread of digital technology and, despite the wishes of some, the movement of people around the world, is likely to continue. 'Globalisation,' as understood by neoliberalism is dead or dying, but the world needs international approaches to a range of issues, from media ownership to climate change, more than ever.

So what does this have to do with cultural policy? The creative industries, as they are sometimes called (and I will use this term, by which I mean the media and cultural sectors broadly, throughout), are often represented as the quintessential twenty-first century industry - employing the welleducated, the mobile and the entrepreneurial. In the recent UK referendum debate, it was made clear that those who worked in the creative industries were committed 'remainers.' One of the industry lobbying organisations in the UK, the Creative Industries Federation (http://www.creativeindustriesfederation.com) reported that its members voted by $96 \%$ to stay in the $\mathrm{EU}$, a figure which, if true, says as much about the unrepresentative nature of the workforce as it does about anything else. It is a sector which often seeks to stress its cosmopolitanism, its openness and internationalism - and rightly so - though in doing so is often in danger of falling into what Craig Calhoun (2002) called, 'the class consciousness of frequent travellers,' a sort of easy liberalism that celebrates the weak ties of global citizenship while scorning the concern for local solidarity of (often) older and poorer fellow citizens.

I want to argue than in looking at the discourse of the creative economy as it has played out over the last fifteen years or so, we can gain some small insight into the drivers of globalisation, the policy issues it raises and why it is meeting such fierce and unhappy resistance. In particular, the absorption of previously progressive cultural policy aims such as increased cultural diversity, an ending of artificial barriers between 'high' and 'low' culture and a recognition of the importance of markets in cultural production, into a much narrower focus purely on 'jobs and growth' has meant that many culture-led developments across the world simply reproduce the sort of heightened inequality associated with the 'knowledge economy.' Cultural workers still often seek to identify themselves with the disenfranchised, but the immanent critique of capitalism, so long assumed to be part and parcel of 'culture,' has in some cases been trade for a much more comfortable seeming but ultimately destructive partnership with the state.

\section{The global role of the 'creative economy'}

The creative economy, as many commentators have pointed out (Cunningham, 2009; Grodach \& Silver, 2013; Turner, 2014) has been a truly globalised discourse, emerging in the particular circumstances of the UK in the late 1990s and travelling via Commonwealth countries such as Australia, as well as parts of Latin America and East Asia and into European cultural policy (for example, the 'Creative Europe' programme from which the UK may soon exclude itself). As it has touched down in different geographic and political contexts, it has of course been changed and contextualised, the economic conditions that drove it in the global north are of course very different from those in East Asia for example. Singapore, South Korea, Hong Kong, Taiwan and eventually China enthusiastically embraced the creative industries as the next step up the value chain from manufacturing, rather than as a response to the loss of manufacturing as in the case of the UK, for example (O'Connor and Gu, 2005; Kong et al, 2006). But at its heart is a vision of economic dynamism, of greater innovation and of varying forms of internationalisation and that I would argue is shared across many of the territories where this is now the dominant policy approach. 
The political implications of this global policy transfer have been much discussed, with a broad distinction in approach captured in Stuart Cunningham's contrast of 'Trojan Horse or Rorschach Blot' (2009). For critics of the creative economy rhetoric, Cunningham argues, it is seen a vehicle for the export of neoliberal policy prescriptions, including but not limited to, urban competiveness, marketization of the arts and the shrinking of a public sphere. He prefers the argument that it is a Rorschach Blot - taking on the contours and imperatives of where it lands, being shaped by them and in turn, changing the discourse itself. Yet as Lee (2016) comments in her analysis of the politics of the creative industries idea in South Korea, the binary of Trojan Horse or Rorschach blot itself is unhelpful. The discourse of the creative economy is embraced and absorbed in different contexts precisely because the political work that it does is seen as useful to different regimes. Its links to the idea of the knowledge economy, a stress on human capital investment, 'flexible specialisation', and strategies of competition through innovation (different goods, not just cheaper goods) are all as welcome in the industrialising contexts of the Global South as they are in the de-industrialised parts of the North.

As part and parcel of a globalisation approach however, it is also bound up with the argument that national economic policymakers are constrained in their ability to shape economic policy. In the case of creative industries, this means that traditional concerns about issues such as media ownership, access to distribution chains or intellectual property were generally dealt with in a way that was consistent with neoliberal, de-regulatory approaches, rather than intervening on behalf of national or local firms.

Even the European Union, which is often associated with arguments against purely market-based approaches to culture and sympathy with 'cultural exception' leanings, has in recent years moved to a more deregulatory approach to culture. Indeed, the EU strategy in media and communication has generally been to argue against the domination of the USA in audio-visual media, while in practice supporting the development of its own large media corporations in this field, which it hopes will be able to compete on equal terms. Strategies that favour large media owners, however, tend to favour large media owners wherever they are located. Such firms are increasingly transnational and thus the EU's gestures towards public service or pubic interest media often lose out to policies that in practice help commercial media companies instead. Recent debates about the proposed Transatlantic Trade and Investment Partnership (TTIP) between the US and the EU, are an example of this as they would appear to weaken national regulation on telecommunications and media policy, for example, making no mention of the provision under EU law for regulators to have an explicit duty to protect citizens interests for example. That the TTIP deal may be slowed or stopped by Brexit and other EU convulsions (as well as by an organised social movement campaign against it), does not disguise the fact that its is part of a continuing de-regulatory approach, even by countries that have traditionally backed the notion of a cultural exception in trade.

Of course the creative economy discourse has not simply been one embraced at the nation state level; cities have been as, if not more, important as agents. The notion of the 'creative city' may originally have carried a strong emphasis on democratisation, both of decision making within urban governance and around the cultural sectors more specifically (Landry \& Bianchini, 1995), but it has long since been absorbed by a narrower focus on growing the creative industry sectors and by the rhetoric of urban competiveness (Oakley \& O'Connor, 2015). At the same time, these policies, as Grodach and Silver note (2013:3), have been conducted within an overall framework of deregulation, privatisation and with a concurrent "reframing of traditional progressive policy goals such as diversity, inclusion, quality of life and sustainability, as facets of urban growth.”

We are used to the absurdities of place-branding which means that the cultural policy documents of nations from Latvia to Korea are often entitled 'Creative' $\mathrm{X}$, but the set of policy tools that accompanies this rhetoric are also remarkably samey: - expansion of higher education on the promise of closer links to 'industry'; - the setting up of agencies to bring together arts, industry and 
technology policies; - the establishment of new spaces of high-end consumption around new cultural buildings in urban areas; - and a stress of measurable goals and outcomes for public spending (Lee, 2016; Comunian et al, 2015). As are the results: - concentration of cultural production in a few urban centres (Grodach, 2016); - a shift from locally-focussed economic development to national policies that emphasise the wider role of 'creativity' and its links to innovation (Oakley, 2009); - the 'creative' economy rethought as 'digital' economy. And everywhere greater inequality. Whether it is through gentrification in the urban centres where creative industries thrive and which eventually leads to the displacement of the very cultural workers on whom they depend (as well as a lot more vulnerable lower income citizens) or through the development of a workforce that is young, mobile, welleducated and increasingly white, male and middle-class (Oakley \& O'Brien, 2015; O'Brien et al, 2016).

There has been much valid criticism to the effect that such developments may support cultural consumption, particularly of a high end sort, but does little to support the kind of cultural production for which are really best known. Shaw (2013) in her work on 'indie subcultures,' in Australia for example, argues that the non-profit and low profit creative activities may well be associated with more balanced economic development. But examining time-series maps of inner Melbourne to look at where these sub-cultural 'scenes' operate, suggests that they are being squeezed into tighter and tighter areas as the relatively cheap rents on which they depend, disappear. As she notes, and other researchers have observed (Lloyd, 2006) cultural workers whether artists, musicians or actors, are rarely marginal in class terms as individuals, but in terms of work and performance space at least, they are often economically marginal, unable to afford 'market' rents particularly in inner-city neighbourhoods.

Cities of course (and towns, neighbourhoods and nations) are far from uncontested spaces and the pro-growth alliances of property developers, city governments and international investors are frequently met with challenges to this version of the creative city. Well-known examples include organisations like Creative Class Struggle, a group of activists who not only take their name from Richard Florida's work, but are based in his current home town of Toronto. From here they write about activities, sometimes artist-led or involving artists, to oppose what they see as the gentrification, segregation and displacement that often follow from creative city urban strategies. Other examples have been the occupation of buildings in Hamburg by artists in an attempt to prevent them being sold to property developers, or squatters and artists joining forces in Berlin-Kreuzberg (Bader and Bialluch, 2009), while in both Amsterdam and Barcelona artists have been at the forefront of attempts to resist gentrification of inner-city neighbourhoods (Van de Geyn and Draaisma, 2009).

In other cases, the new politics of place, symbolised perhaps by the various Occupy movements, has witnessed alliances with new forms of cultural worker organisation, such as the Arts \& Labor groups which emerged from Occupy Wall Street in New York and seeks explicitly as De Peuter \& Cohen note (2015) to form alliances with other workers who share the common condition of precarity. The growth of a 'precariat' (Standing, 2011), whether one think this represents a class in any meaningful sense or not, obviously allows for such alliances and conditions could be said to be favourable with a growth of a much more insecure and indebted middle class, but there are significant challenges to such alliances notably within the cultural industries themselves.

\section{The creative industries and inequality}

I have argued previously that in its early incarnation, the creative industries idea had progressive possibilities - seeking a diversity of cultural expression, more spatially balanced economic growth and a recognition of cultures and communities that had been hitherto marginalised. But in the case of the Global North and the UK in particular, the progressive promise of creative industries development largely failed to materialise. This is not to suggest that the sectors themselves did not thrive, some 
undoubtedly did despite the challenge of digital technology to traditional models of paid-for content. But the wider effect of this form of economic development on society has been less beneficial. The claims of social benefits, which have traditionally been as much a part of the cultural policy 'offer' as claims for economic growth have proved not only unfulfilled, but in many cases these developments have exacerbated the very problems they claim to address.

It is now abundantly apparent that labour in the cultural sectors (whether employed or self employed) is highly socially skewed. The representation of black and other ethnic minority workers in the UK's media industries for example, declined from 7.4 per cent in 2006 to 5.4 per cent in 2012 and in all sectors of the creative industries (other than general information technology) black workers are under-represented. This is of even greater concern when one looks at the geographic clustering of media employment in the UK, much of which centres around London and the South East, where ethnic minorities make up about a third of the working age population.

Women are similarly under-represented, just under 36 per cent of jobs in the creative industries are filled by women compared to nearly 47 per cent in the economy as a whole. The area with the highest proportion of jobs for women is, 'museums, galleries and libraries', where almost 70 per cent of the workforce is female - a reflection of the fact that, among others things, female labour is often concentrated in lower-paid employment.

Alongside this gender and ethnicity-based inequality, social class inequalities are becoming very marked. People from working class background are under-represented in most creative occupations, while people whose parents have professional or managerial jobs are over-represented, particularly in certain sectors such as publishing, advertising and music. Various explanations have been advanced for this, the most popular of which is the growth in unpaid internships as a route into cultural work something that young people from working class backgrounds are less likely to be able to undertake than those whose parents can continue to fund them after formal education finishes (or offer them rent-free accommodation at home).

But other factors come into play as well. Research suggests that the social networks that people form, particular in prestigious school or colleges, the social networks that their families may have - knowing people who work in the cultural sectors already for example- and the social self-confidence that comes with a privileged education, all have an impact in a form of employment where being able to cultivate and use social networks is vital. Recent research on the acting profession, for example (O'Brien et al, 2016) suggests that actors from working class backgrounds earn less throughout their working lives even if they 'make it' into the profession - as the likelihood of having an agent, having the right sort of agent, knowing the right sort of contacts and being able to survive spells of unemployment, are all in part determined by social background.

So marked is this phenomenon that even the mainstream media in the UK has started take notice with a series of media reports about the dominance from the TV schedules to the popular music charts of a highly-privileged elite, often privately-educated, white and male. This is echoed in the US or example by the by-now annual furore over the Oscars shortlist with its apparent exclusion of people of colour. These are high profile examples, but everywhere the links - political and economic - between cultural workers and the rest the populace are fraying. A model of creative industry development has supported the professionalization of a verity of cultural jobs and a large growth in the workforce. The precarity of that workforce is obvious - it is far from consistently privileged - but the ability of working class people and people of colour to undertake this sort of work professionally has been severely attenuated, producing industries, which while they may retain liberal or leftist leanings politically, are deeply disconnected. 


\section{A new model for the creative economy?}

In his contribution to Unesco's 2013 Creative Economy Report, the Australian geographer Chris Gibson argues that the key to more balanced global cultural economy is to recognise path dependency and the need for a pluralistic view of development. In other words, different industries in different contexts should have divergent paths and there is no single model - or even a few models - that they need to follow. The growth of popular cultural practices drawn from multiple global sources - Tanzanian hip hop, Mexican telenovellas, Nigerian moviemaking, South Korean pop music and so on - all attest to the growth of cultural production outside of the traditional 'centres' of global cultural industries. Analysis of the Indian or Nigerian film industries for example, shows very different trajectories to that of Hollywood, characterised by informal networks, localised funding and a more fragmented approach to ownership and distribution (Miller 2012; Mukherjee 2008).

This notion of 'path dependency' suggests that history matters and that policy development, even at a global level, has to take account of the way in which particular cultural scenes were formed. Gibson gives the example of surfboard-making in Hawaii, which was 'exported' to other places, by Hawaiian surfers, demonstrating their skills. Surfing is now popular in pretty much any country with a coastline but surfboard manufacture remains located in a few global centres where deep subcultures have allowed an industry to develop, based on social relationships, informal loans and sufficiently large tourist and surfing communities to act as consumers. This is a rather specific example, but point is that policy initiatives and economic development are not enough without these local, cultural factors; yet the creative economy model that has been pursued nationally, locally and internationally is not only insensitive to the time and the local knowledge needed to support such localised production centres, it is actively undermining the conditions of their existence.

For many cultural activists, the idea of a more progressive international cultural policy must seem impossibly remote. The 2013 Creative Economy Report signalled some sort of shift away from a single, global approach to developing the creative industries. But the reality of trade treaties, unchallenged media ownership and increasing corporate dominance, including of social media networks, makes this a difficult arena in which to challenge the creative economy approach. More promising perhaps are the activities of non-state actors, such as workers' organisations or urban coalitions. Many cities and towns are considering a finer-grained, smaller and more localised approaches to creative industries, where lifestyle businesses and not-for-profits are not seen as failed business models, but as ways of sustaining meaningful work in a steady state or low-growth economy. The danger for these approaches, promising though many are, is that those able to undertake them are increasingly cut off from the societies they work in. Unless the creative industries can find way of addressing their own labour market problems and thus develop a more inclusive and representative workforce, the sense opf the cultural sectors as source of progressive political alternatives will begin to seem absurd.

\section{References}

Bader, I. and Bialluch, M. (2009) 'Gentrification and the creative class in Berlin Kreuzberg', in L.Porter and K.Shaw (eds) Whose Urban Renaissance? An International Comparison of Urban Regeneration Strategies, London: Routledge.

Calhoun, C. (2002) The class consciousness of frequent travellers, The South Atlantic Quarterly 101.4 (2002) p. 869-897 
Cunningham, S. (2009) 'Trojan Horse or Rorschach Blot? Creative industries discourse around the world', International Journal of Cultural Policy, 15(4): 375-86.

De Peuter, G \& Coen, N. (2015) Emerging Labour Politics in Creative Industries in Routledge Companion to the Cultural Industries, Oakley, K \& O'Connor, J (Eds). Routledge.

Comunian, R, Gilmore, A \& Jacobi, S. (2015) 'Higher Education and the Creative Economy: Creative Graduates, Knowledge Transfer and Regional Impact Debates'. Geography Compass, Vol 9, 7 p. 371-383

Grodach, C., and Silver, D. (eds) (2013) The Politics of Urban Cultural Policy: Global Perspectives, London: Routledge.

Grodach, C. (2016) Mapping the arts: industry concentrations, distribution and change i the US, 1980-2010, International Journal of Cultural Policy, Volume 22, Issue 3.

Kong, L., Gibson, C., Khoo, L-M. and Semple, A-L. (2006) 'Knowledges of the Creative Economy: towards a relational geography of diffusion and adaptation in Asia,' Asia Pacific Viewpoint, 47: p. $173-94$

Landry, C \& Bianchini, F. (1995) The Creative City. London: Demos

Lee, HK (2016) Politics of the Creative Industries Discourse, in International Journal of Cultural Policy, Volume 22, Issue 3

Miller, J. (2012) 'Global Nollywood: the Nigerian movie industry and alternative global networks in production and distribution', Global Media and Communication, 8(2): p. 117-133.

Mukherjee, A. (2008) 'The audio-visual sector in India', in Barrowclough, D. and Kozul-Wright, Z. (eds) Creative Industries and Developing Countries: Voice, Choice and Economic Growth, London: Routledge.

Oakley, K. (2012) 'Rich but divided... the politics of cultural policy in London', in Cultural Policy and Governance in a New Metropolitan Age, Volume 5, The Cultures and Globalization Series, London: Sage.

Oakley, K. (2013) 'A different class: politics and culture in London', in C. Grodach and D. Silver (eds) The Politics of Urban Cultural Policy: Global Perspectives, London: Routledge

Oakley, K. \& O'Connor, J. (2015) Culture and the City in in Routledge Companion to the Cultural Industries, Oakley, K \& O'Connor, J (Eds). Routledge.

Oakley, K. \& O'Brien, D. (2016) Learning to labour unequally: understanding the relationship between cultural production, cultural consumption and inequality, Social Identities: Journal for the Study of Race, Nation and Culture. DOI:10.1080/13504630.2015.1128800

O’Brien, D., Laurison, D., Friedman, S., Miles, A. (2016) 'Are the Creative Industries Meritocratic?' Cultural Trends (forthcoming)

O'Connor, J. and Gu, X. (2006) 'A new modernity? The arrival of 'creative industries' in China'. International Journal of Cultural Studies, 9:3: p. 271-283.

Standing, G. (2011) The precariat: the new dangerous class. London and New York: Bloomsbury Academic

Turner, G. (2014) 'Culture, politics and the cultural industries: reviving a critical agenda', in K. Oakley and J. O'Connor (eds) The Routledge Companion to the Cultural Industries, London: Routledge.

UNCTAD (2008) The Creative Economy Report: the Challenge of Assessing the Creative Economy: Towards Informed Policy-Making, New York: UNCTAD, available at: http://unctad.org/en/docs/ditc20082cer_en.pdf 
UNCTAD (2010) The Creative Economy Report: Creative Economy: a Feasible Development Option, New York: UNCTAD.

Unesco (2013) The Creative Economy Report: Widening Local Development Pathways, New York: Unesco.

Van de Geyn, B. and Draaisma, J. (2009) 'The embrace of Amsterdam's creative breeding ground', in L. Porter and K. Shaw (eds) Whose Urban Renaissance? an International Comparison of Urban Regeneration Strategies, London: Routledge. 